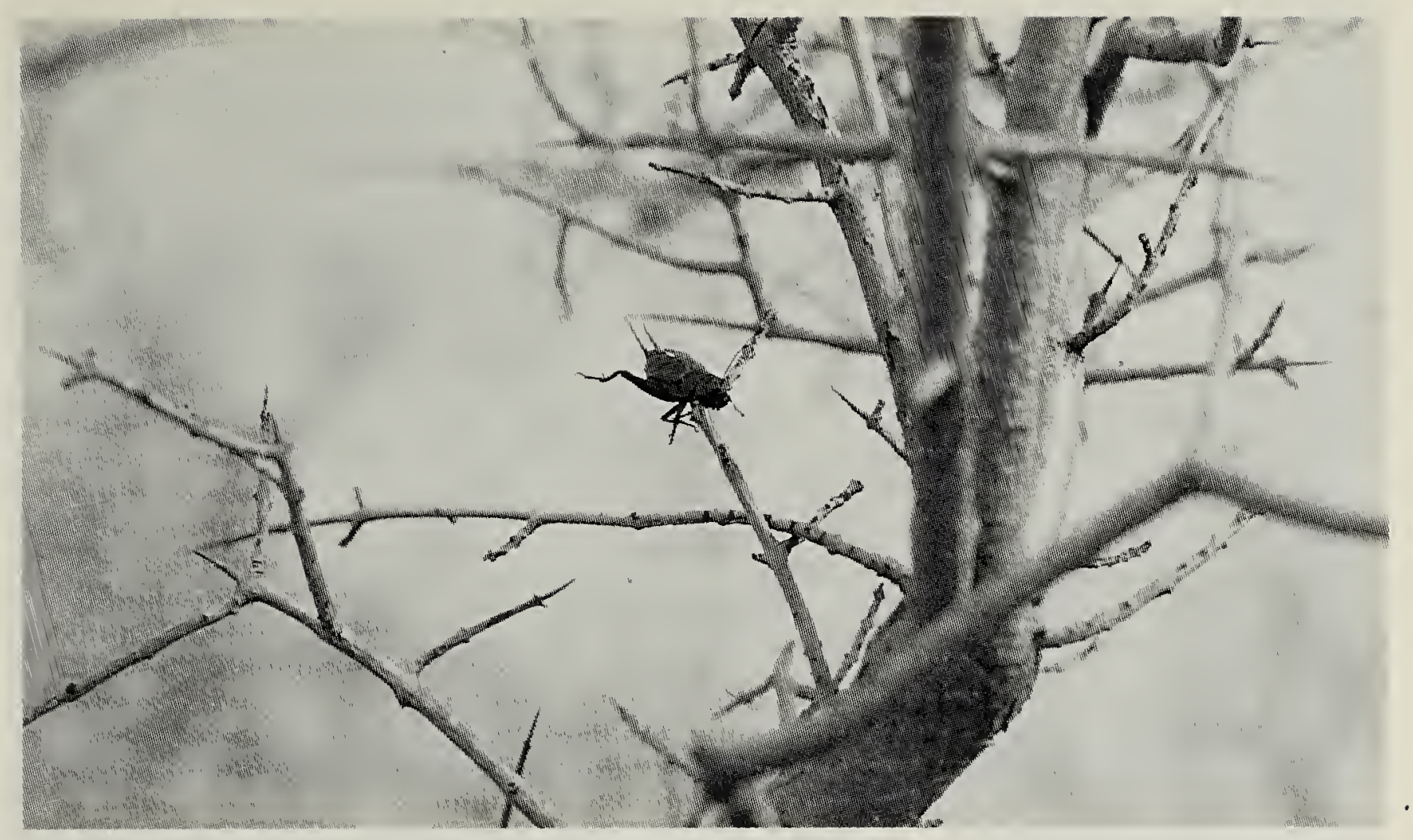

Cricket impaled by Loggerhead Shrike

Doug Collister

is how shrikes sometimes deal with their prey.

Whatever the reason, I feel fortunate to have had this experience. Loggerhead Shrikes are threatened in Western Canada and endangered in the east. ${ }^{2}$ Habitat loss is thought to be part of the problem, especially large-scale conversions of pasture to cropland. 2,3 Matador is particularly valuable in this light since much of the pasture (including the spot I was lying on) is a rare and significant type of mixed-grass prairie which has never been cultivated. As shrike habitat and for many other reasons we should continue to protect and study it.

1. EHRLICH, P.R., D.S. DOBKIN and D. WHEYE. 1988. The birder's handbook: a field guide to the natural history of North American birds. Simon \& Schuster Inc., New York, NY. 785 pp.

2. JOHNS, B., M. CADMAN, D. BIRD, R. BJORGE, K. DE SMET, W. HARRIS, D. HJERTAAS, P. LAPORTE and R. PITTIWAY. 1994. National recovery plan for the Loggerhead Shrike. Recovery of Nationally Endangered Wildlife Committee Report No. 7. Ottawa. $32 \mathrm{pp}$.
3. TELFER, E.S. 1992. Habitat change as a factor in the decline of the western Canadian Loggerhead Shrike, Lanius ludovicianus, population. Can. Field-Nat. 106:321-326.

- Glenn C. Sutter, Dept. of Biology, University of Regina, Regina, SK. S4S 0A2.

\section{GOPHER VS CHIPMUNK - AND THE WINNER IS! THE GREAT PEANUT CAPER}

First, a little background to my story. As I live in Regina, I really enjoy visiting a friend who lives on a farm east of Southey. On several previous occasions, I had fed shelled peanuts to a "Least" chipmunk that showed up one day by the house. The chipmunk would come up to my hand and take an unshelled peanut from my fingers. I observed him eating it. He would slowly unshell it, carefully take the husk from it and eat it with great refinement.

After a couple of weeks of throwing peanuts to this chipmunk, I began to notice that a "Thirteen-striped" gopher (yes, I counted his stripes) was observing (from a distance) 


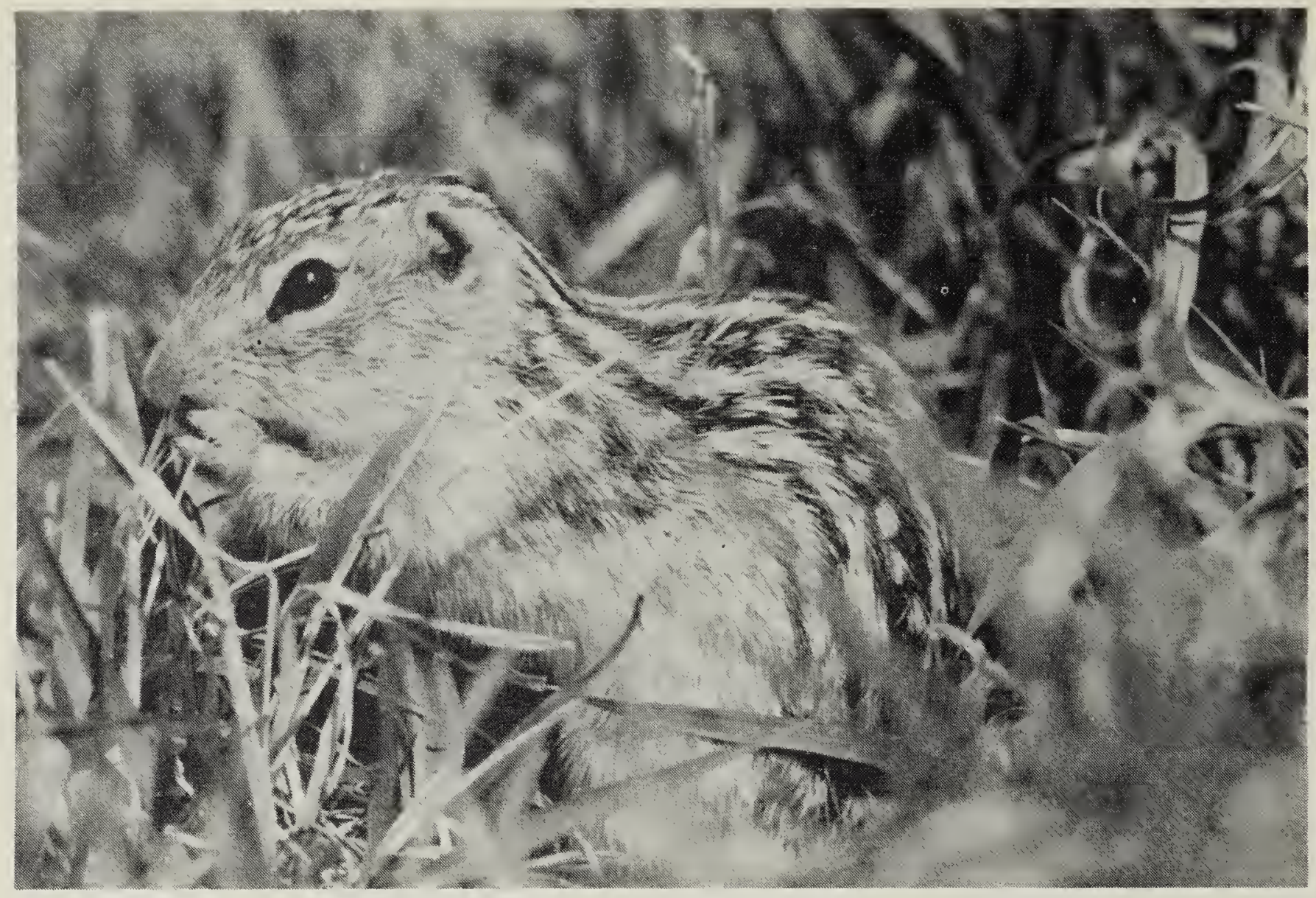

Wayne Lynch

what was going on. I didn't think that this gopher would come anywhere near me so I tossed a peanut far in his direction. He grabbed it, put it in his mouth and took off. I began to toss them closer and he cautiously got them. After a half dozen tosses, I threw caution to the wind and held a peanut shell in my fingers. Sure enough, he came up, grabbed his prize and headed for the hills (so to speak!). After a few more times of taking peanuts from my hand, he proceeded to eat them next to my feet. He even let me rub the top of his head. After a few pats he moved a few inches away, seeming more annoyed than fearful. His eating habits were nothing like that of the wellmannered chipmunk. This gopher would grab the peanuts, attack the shell, with husks flying, and shove them into his mouth and into his side pouches. When these pouches became full (very full), he would dart off to unload his treasures in some secret hideaway.

One afternoon in mid-June 1995 I was out enjoying some shade next to the garage when I noticed the gopher close at hand. I reached for my supply of peanuts (which by this time I never left the house without) and soon had the gopher eating from my fingers. Well, at this time the chipmunk also showed up. Having the two show up at the same time was indeed a first! I tossed peanuts at the chipmunk to keep him from getting too close to me (and the gopher) for fear that the gopher would attack him. Once the gopher saw that the chipmunk was also taking advantage of these peanuts, he proceeded to take peanuts into his mouth at even a faster rate! I continued to feed both the gopher and the chipmunk, which were on opposite sides of my lawnchair. At one point, I suspect I must have been too slow in giving the chipmunk his next peanut as he rushed over to the gopher who had a stash beside him. They eyed each other and I became rather concerned that the gopher would go after the chipmunk. After a 30-second stare, the chipmunk must have realized he was outmuscled and took off. 


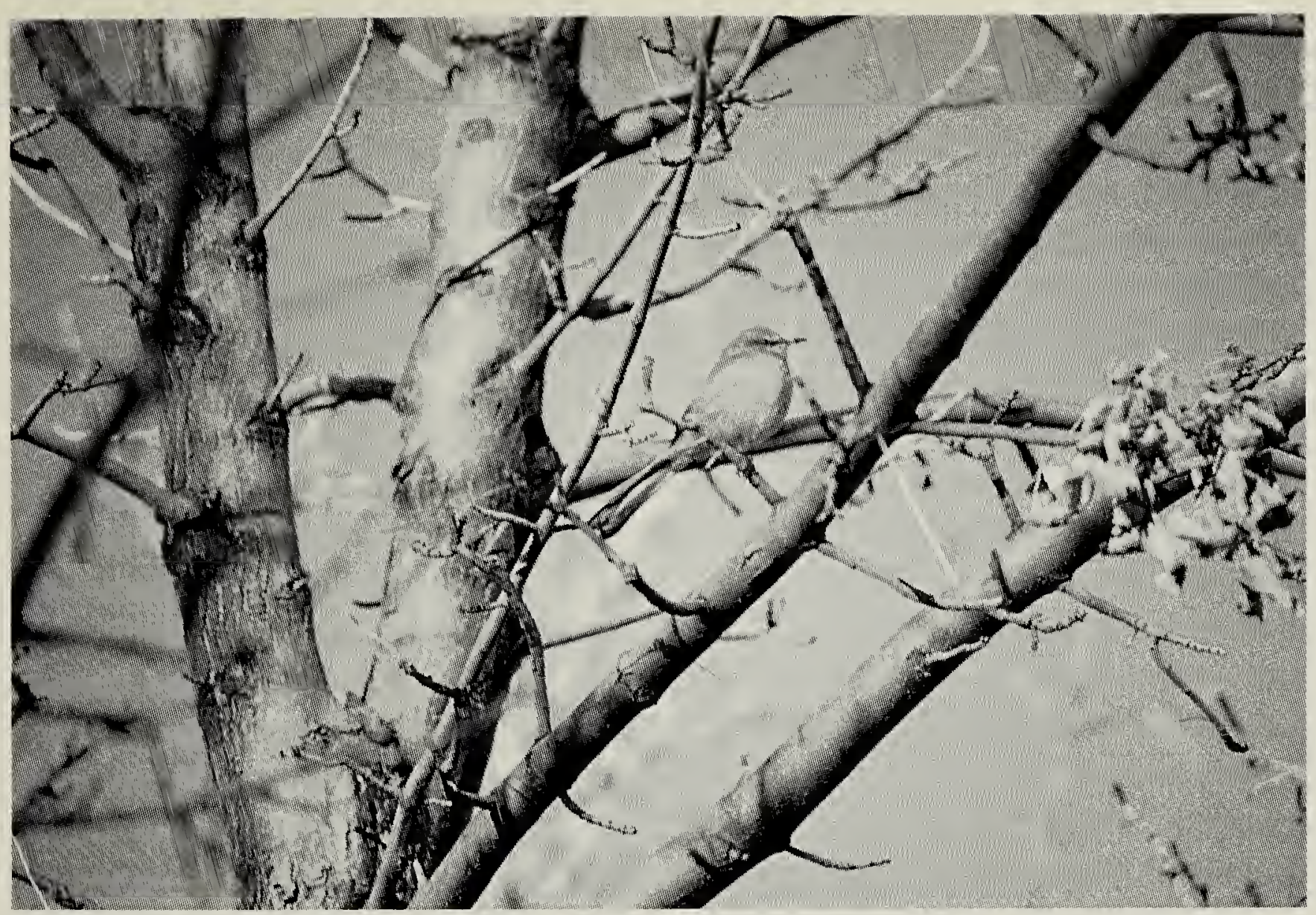

Northern Mockingbird

Doug Collister

The gopher continued to store peanuts in his mouth - clearly the winner! On a separate note, while feeding the gopher, I noticed a caterpillar moving across the grass. I never gave it a second thought until I saw the gopher pick it up and begin to spin it in his paws. He would spin it for a few seconds and then stop and look at it. If the caterpillar moved, he would once more spin it, stop and stare at it. After four spins, he stopped and the caterpillar lay still. It was then that he proceeded to eat it. It was something that I didn't think he would eat, but I'm beginning to discover that with nature, you just never know!

- Carol Bessant, \#901 - 2720 College Avenue, Regina, Sḱ.

\section{UNUSUAL BIRDS IN CENTRAL SASKATCHEWAN}

Last summer (1994) we stayed in a number of different towns in the southwestern United States enjoying the oases of lush grass and spread-

ing trees between the miles of desert. In three places we spotted mockingbirds, our first sightings ever, though we had seen its cousin, the catbird, in central Manitoba.

One stay was for two weeks in June and we often saw the mockingbirds flying around the lush garden, often in pairs; the large white patches on their wings as well as on their tails (which often cocked up on landing) were quite distinctive. Their song was delightful too, and they became my favourite bird then.

On 16 October 1994, in Prince Albert, I was walking in the Crescent Heights area when I saw a bird alight on a post by the side of the street a robin I thought, at a distance, but as I came nearer it cocked its tail and flew away, showing distinctive white patches quite clearly. I mentioned this to friends and they said they had seen a strange bird in the garden and couldn't think what it was. ... Further along the street, there it was again, scrabbling about 